\title{
The Contribution of Group- Based Micro and Small Enterprises in Employment Creation and Income Generation: Evidence from Woreda Fourteen of Kolfe Keranio Sub-City, Addis Ababa, Ethiopia
}

\author{
Tolasa Tafa Wami \\ Oromia State University
}

\begin{abstract}
The main objective of this study is to investigate the Contribution of Group-Based MSEs (construction, manufacturing and service enterprises) to employment creation and income generation in the Woreda 14, Kolfe keranio Sub city. Unemployment and low income are one of the present situations in urban and cities of Ethiopia. The government of Ethiopia has formulated a policy to mitigate the overwhelmed problem by fostering micro and small enterprises. During the study, primary data were collected from 80 owners and 76 employees of MSEs'. In addition, secondary data were collected from Woreda 14 MSEDO, Kolfe keranio Sub city MSEDO, and Addis Ababa MSE Development Bureau. Both quantitative and qualitative approaches were applied to analyze data. The finding of the study shows that the enterprises provide income and employment opportunities. It provides annual average of minimum 5-7 and maximum 17-23 employment opportunities in the last five the years. The annual average income of the enterprises was at the minimum ranging between 30,000-50,000Birr and maximum ranging between 141,001-200,000 Birr. However, the roles of micro and small scale enterprises have been left unexploited in providing income and employment due to lack of working place, insufficiency of finance or credit facility and like. Thus, the government and other concerning bodies should modernize working procedure, promoting micro finance institutions and provide working premises in the appropriate place in order to boost the influence of micro and small enterprises in generating income and employment opportunities for the people.
\end{abstract}

Keywords: Micro Enterprise, Small Enterprise, Manufacturing, Construction and Service Sector

DOI: $10.7176 / \mathrm{JAAS} / 55-02$

Publication date:May $31^{\text {st }} 2019$

\section{Acronyms}

ADLI- Agricultural Development Led Industrialization

CSA_Central Statistical Authority

FDRE- Federal Democratic Republic of Ethiopia

FeMSED- Federal Micro and Small Scale Enterprise Development Agency

FMSES- Federal Micro and Small-Scale Enterprises Strategy

GDP- Gross Domestic Product

GTP- Growth and Transformation Plan

IDS- Industrial Development Strategy

ILO- International Labor Organization

MDG-Millennium Development Goals

MoFED- Ministry of Finance and Economic Development

MoTI- Ministry of Trade and Industry

MSE- Micro and Small Enterprise

MSEDO- Micro and Small Scale Enterprise Development Office

MUDC- Ministry of Urban Development and Construction

NGO- Non-Governmental Organization

SA-Sahara Africa

SME- Small and Medium Enterprise

SDPRP- Sustainable Development and Poverty Reduction Program

UNDP- United Nations Development Program

\section{Introduction}

\subsection{Background of the Study}

The vast majority of firms around the world fall into the category of micro, small or medium-sized enterprises. In terms of enterprises, more than $95 \%$ fall into this category; but even in terms of employment in low and lower-middle income countries, more than 50\% of employees work in companies with fewer than 100 employees (Ayyagari, Demirguc-Kunt and Maksimovic, 2011). In today's globalization of world trade, a 
substantial role is being assigned to the private sectors in many developing nations. In line with this, there has been the emergence of micro and small enterprise (MSE) sector as a significant element for economic development and employment. MSE Sector has seen as the engines of employment, alleviating poverty and upgrading the standard of living of citizens which is understood by both developed and developing nations (Belay kinati et al.., 2015).

In developed countries, the share of the enterprises is even larger accounting, on average about $50 \%$ to GDP and $60 \%$ to employment. Thus, naturally, as economies grow, the share and contribution of these enterprises in the economies of developing countries will improve. In these economies, the expansion of these enterprises is doubly important as they are closely associated with the relatively poor and especially so with disadvantaged groups of women and youth (Robu M., 2013). In developing countries, entrepreneurial activities and the associated Micro and Small Enterprises (MSEs) are particularly salient among the urban poor. These enterprises provide employment opportunity and source of income, by which these poor people withstand causes and seeds of extreme poverty. Consequently, encouraging and supporting the establishment and expansion of Micro and Small Scale Enterprises (MSEs) is one of the development paths opted by the governments of developing countries to reduce unemployment and the resultant poverty (Daniels and Mead: 1998). Governments of various least developed nations are allocating ample resources for promoting the MSE sector because they see MSEs as engines of employment; tools of alleviating poverty and improving equality (Gomez, 2008). Apart from the government focus and efforts, various national and international nongovernmental organizations (NGOs) have also spent considerable attention and resources, directly or indirectly, on boosting up MSEs due to their ability to grow tremendously at the peak of the economic crisis of the 1980s even exhibited unique strength in the face of recession (Mulugeta, 2011).

In recognition of the importance of MSEs to the economy in terms of employment creation, income generation, and equity, the government of the Federal Democratic Republic of Ethiopia (FDRE), has adopted National Micro and Small Enterprise Development Strategy in 1997. Following this, the Federal Micro and Small Enterprises Development Agency (FeMSEDA) was established by council of Ministers in 1998 (proclamation No.33/1998) with the objective to encourage, coordinate and assist institutions which provide support for the development and expansions of MSEs in the country at large. The primary objective of the strategy framework was to create a favorable environment for MSEs so that MSEs could facilitate economic growth, create long-term jobs, strengthen cooperation between MSEs, provide the basis for medium and large scale enterprises and promote export. In this strategy framework, the government prioritized those enterprises with features like manufacturing and processing various commodities, self-employment particularly by disabled and unemployed youth, start-ups and expanding firms owned by women etc. Federal Micro and Small Enterprises Development the agency has been established as an autonomous government institution under the supervision of the Ministry of Urban Development and Construction. The primary goal of the agency is to meticulously implement the strategies mentioned above (MUDC, 2013). To implement the MSE policies and strategies, Regional Micro and Small Enterprise Development Agencies have been established. In Ethiopia, the idea of Micro and Small Enterprise Development emerged as a promising agenda in the 1980s to reduce poverty, ensure sustainable development and productivity as well as to economically empower both men and women.

\subsection{Statement of the Problem}

The government of the Federal Democratic Republic of Ethiopia has employed the promotion and development of MSEs as a tool and strategy that can have a profound effect on reducing urban poverty, creating employment and bringing about overall growth in the business sector( Tegegne and Meheret : 2010). In the government's Plan for Accelerated and Sustainable Development to End Poverty (PASDEP) of 2005-2010, according to the Ministry of Finance and Economic Development (MoFED), it is shown that there is a plan to reduce urban unemployment via promoting MSEs and creation of 1.5 million new job opportunities (Mulugeta: 2011). The EPRDF adopted Agricultural Development Led Industrialization (ADLI) and private sector development strategy in 1995. An element of these strategies was focused on micro and small scale enterprises development: Among the principal objectives Federal Micro and Small-Scale Enterprises Strategy (FMSES) and Regional Micro and Small-Scale Enterprises Strategies (RMSES) are exploitation of local raw material, creation of productive job opportunities, adoption of new and appropriate technologies, and enhancement of the development of MSEs which have wide-ranging backward and forward linkages. The highest national policy framework (the GTP) clearly states that micro and small enterprises constitute the main strategic direction of industrial development $\|$ in the country. The GTP recognizes that the expansion of MSEs in urban areas will result in large scale job creation and thereby poverty reduction (MOFED, 2010).

In relation to FDRE government, in 2004 the government of Addis Ababa began the Micro and Small Enterprise development Program with the objective to reduce poverty and unemployment to less than $20 \%$ in 2012, provide people with an income and employment. But the study conducted by MUDC (2013) identified a number of challenges and constraints hindering the growth of MSEs. These challenges were manifested in terms 
of capital, technology and employment growth trends (Ibid). An enterprise in other regional cites indicated that shortage of finance $(42 \%)$ to expand their business was their principal challenge, followed by lack of working pre $^{1}$ mise (28.3\%); and lack of access to market or absence of linkage to market. The study (MUDC (2013)) also showed that lack of access to land has been one of the most crucial bottlenecks (26.4\%) in Addis Ababa, problem of finance $(25.6 \%)$ and access to market $(25.1 \%)$ were among the strong factors inhibiting the growth of these enterprises in the capital. However, according to UNDP (2014) report indicates that Poverty levels have reduced from $38.7 \%$ in $2004 / 2005$ to $32.7 \%$ in $2008 / 09$ and to an estimated $27.8 .2 \%$ in $2011 / 2012$ (MoFED MDG Report 2012).

According to CSA 2011/12), the national unemployment rate was $3.1 \%$ in $1994,8.2 \%$ in $1999,5.4 \%$ in 2005 , and $3.7 \%$ in 2007 . The survey also indicated that unemployment rate in urban areas estimated at $17.5 \%$ of which $11.4 \%$ are males and $24.2 \%$ are females and high youth unemployment prevalence, $27 \%$ and $18.3 \%$ for age group 20-24 and 25-29 respectively. Thus, In Ethiopia micro and small enterprises have got a great attention in reduction of poverty. The excursion made in the MSE strategy of Ethiopia in brief reveals the vastness of the contribution of MSEs in the entire economy has been immense. Studies conducted by MoTI, 1997 as cited in GTP, 2010, these areas rightly point out that MSEs have been on the forefront in employment creations, poverty reductions, proliferations of entrepreneurships and thus economic development concurrently. Most previous studies (Bereket and Tadesse, 2010) which were conducted on micro and small enterprises mainly focus on the role of individually and cooperatively owned micro and small enterprise in employment creation and income generation.

Another study conducted was on the contribution of group-based MSEs to the Local Economy and Social Development (Endalsasa Belay, 2012). Therefore this study focus on assessing the contribution of group- based MSE sector in employment creation and income generation in selected enterprise (manufacturing, construction, and service) simultaneously woreda 14 of Kolfe Keranio sub-city. This was the knowledge gap that this research was trying to fill. Hence, in this study, the researcher has tried to investigate the contribution of the three sectors of MSEs to employment creation, and income generation.

\subsection{Objectives of the study}

\subsubsection{General Objective}

The overall objective of the study is to examine the contribution of group- based micro and small enterprises in employment creation and income generation in Woreda 14, Kolfe Keranio sub-city of Addis Ababa by analyzing the characteristics \& performances of the MSEs.

\subsubsection{Specific Objectives}

The specific objectives of the study are to:

Examine the contributions of group based MSE sector to the employment creation.

To assess the contribution of group-based MSEs in income generation.

\subsection{Research Question}

The study will attempt to answer the following basic questions about the group- based micro and small enterprises.

What are the contributions of micro and small enterprise in employment creation?

What are the contributions of MSEs in income generation?

\section{Literature Review}

\subsection{Definition of Micro and Small Enterprise}

The definition and types of micro and small enterprises differ from country to country and there is no universally stated definition for micro and small enterprises. Depending on their realities and objectives, each country has to establish its own definition for them. For instance, in our country, Ethiopia, micro and small enterprises are given different meanings at different times. Most commonly, micro enterprise is enterprises with ten and less employees, while small enterprise is enterprises with 10 to 50 employees (Farbman and Lessik, 1989).So, according to their purpose and intention, different countries defined micro and small enterprises differently. However, the parameters generally applied by most countries, single or in combination are: capital investment in plant and machinery, number of workers employed, or volume of production or turnover of business (Endalsasa Belay, 2012).

The following table shows the definitions of micro and small enterprise in different countries. 
Table1: Definitions of micro and small enterprise in different countries

\begin{tabular}{|l|l|l|l|l|}
\hline Country & Enterprise division & Categories of each enterprise & Human Resource & Total Asset \\
\hline \multirow{4}{*}{ Ethiopia } & \multirow{4}{*}{ Micro enterprise } & Industry & $\leq 5$ & $\leq \$ 6000$ \\
\cline { 3 - 5 } & & Service & $\leq 5$ & $\leq \$ 3000$ \\
\cline { 2 - 5 } & Small enterprise & Industry & $6-30$ & $\leq \$ 9000$ \\
\cline { 2 - 5 } & & Service & $6-30$ & $\leq \$ 3000$ \\
\hline \multirow{4}{*}{ India } & Micro enterprise & Manufacture & - & $\leq \$ 50,000$ \\
\cline { 2 - 5 } & & Service & - & $\leq \$ 20,000$ \\
\cline { 2 - 5 } & Small enterprise & Manufacture & - & $\leq \$ 1$ million \\
\cline { 2 - 5 } & & Service & - & $\leq \$ 0.4$ million \\
\hline \multirow{5}{*}{ South Africa } & Micro enterprise & - & $1-4$ & $\leq \$ 3400$ \\
\cline { 2 - 5 } & Medium enterprise & - & $5-49$ & $\leq \$ 136000$ \\
\cline { 2 - 5 } & Small enterprise & - & $50-99$ & $\leq \$ 544000$ \\
\cline { 2 - 5 } & Vicro enterprise & - & $1-4$ & $\leq \$ 15000$ \\
\cline { 2 - 5 } & Sery small enterprise & - & $10-20$ & $\leq \$ 94000$ \\
\cline { 2 - 5 } & Small enterprise & - & $20-50$ & $\leq \$ 734,000$ \\
\hline
\end{tabular}

Source: Central Statics Agency (CSA), 2010

\subsection{Contribution of Micro and Small Enterprise in generating income and employment}

Micro and small enterprises play various roles in economic development of a nation that include building up local production structure, creating employment opportunity and achieving a fairer distribution of national resource, income, knowledge and power, help to promote rural industrialization, and promote export market (Mulugeta, 2008). The sector is contributing immensely to economic growth, more importantly to employment and job creation in both developed and developing nations. In developed countries it provides $60-70$ percent of employment opportunities. In developing countries it provides 45 percent of total employment and 33 percent of Gross Domestic Product (GDP). In Africa and Asia, the micro and small enterprise sector constitutes the majority of the working population. For example, in South Africa it contributes about 84 percent of employment and in Kenya, the sector contributes immensely to the macroeconomic development of the economy by providing employment, training entrepreneurs, generating income and improving the living standard of most of the low income households in the country. Furthermore, the sector contributes about 71percent to employment and accounts for about 92 percent of businesses in Ghana respectively (J. Abor, and P. Quartey, 2010).

In Ethiopia micro and small enterprises were created 806,322, 1,223,679, 2,500,000, and 2,800,000 job opportunities for the people in 2011/2012, 2012/2013, 2013/14, and 2014/2015 respectively moreover, micro and small scale enterprises have a crucial contribution in improving the welfare, standard of living, income levels and social stability of people. Such contribution is different from the enterprise to the enterprise, for instance construction sector, service and industry sector has provided an annual average income of 4,948, 4,983 and 3,234 birr respectively for the owners of the enterprises (Tadesse 2010). However, the roles of micro and small enterprise were found to be unexploited in Ethiopia due to different factors like lack adequate market, finance, manpower and other necessary assistance and support from government. Therefore, in order to increase the capacity of the MSE sector and thereby their contribution to employments creation and income generation these real and other related challenges or constraints should be solved or at least minimized

\section{Research Methodology}

\subsection{Research Design}

The study was conducted by using descriptive research design in which both qualitative \& quantitative approach were used to get the advantage of both. The reason for using this design is that it enables the research to describe the roles of MSEs in employment and income generation in Woreda 14 of Kolfe Keranio sub-city.

\subsection{Sources of Data}

In order to achieve the objective of the study both primary and secondary data were collected and used. The primary data were collected from study area (Woreda 14, Kolfe keranio sub-city) using observation method, interview, and questionnaires. The secondary data had been collected from different books, articles, journals, reports and other published and unpublished materials to contribute for success of the study.

\subsection{Target Population}

The target population for this descriptive study was the group-based micro and small enterprises of Woreda 14 , 
Kolfe Keranio sub-city with the population of 113 enterprises. The focuses of this study were owners, managers and employees of MSEs.

\subsection{Sample and sampling Techniques}

Sampling technique is one of the components of research methodology. In the study area, there is about 113 groups- based micro and small enterprises, 15 out of which are service sectors, 16 are manufacturing industries, and 82 are construction. From these 29 constructions, 6 manufacturing and 5 service enterprises have been selected through proportional stratified sampling method. Specifically 156(i.e.76 employees \& 80 owners) were selected using simple random sampling method as unit of analysis.

Table 2: Sampled enterprise, owners and employees (unit of analysis)

\begin{tabular}{|l|l|l|l|l|l|l|}
\hline $\begin{array}{l}\text { Name of } \\
\text { Enterprise }\end{array}$ & $\begin{array}{l}\text { No.of sampled } \\
\text { enterprise }\end{array}$ & $\begin{array}{l}\text { Total } \\
\text { enterprise } \\
\text { owner }\end{array}$ & $\begin{array}{l}\text { No. } \\
\text { sampled } \\
\text { Enterprise } \\
\text { owners }\end{array}$ & $\begin{array}{l}\text { Total } \\
\text { employees } \\
\text { in Sampled } \\
\text { enterprise }\end{array}$ & $\begin{array}{l}\text { 20\% of total } \\
\text { employees } \\
\text { was } \\
\text { sampled } \\
\text { enterprise }\end{array}$ & $\begin{array}{l}\text { Unit of } \\
\text { analysis }\end{array}$ \\
\hline Construction & 29 & 188 & 58 & 260 & 52 & 110 \\
\hline Manufacturing & 6 & 56 & 12 & 100 & 20 & 32 \\
\hline Service & 5 & 50 & 10 & 22 & 4 & 14 \\
\hline Total & 40 & 294 & 80 & 382 & 76 & 156 \\
\hline
\end{tabular}

\subsection{Methods of Collecting Data}

In this descriptive type of research, observation, interview, and questionnaires were mainly used to collect primary data form sampled respondents. In addition to primary data, secondary data were collected from both published and unpublished materials like Central Statistical Agency (CSA), Ministry of Trade and Industry, Addis Ababa Micro and Small Enterprise Development Bureau, and Woreda 14 of administrations of the Kolfe Keranio sub city.

\subsection{Method Data of Analysis}

Data collected from the completed questionnaires were inspected first of all, cleaned, transformed and ordered into useful information for easy comprehension. After that the data were modeled into coded categories to facilitate analysis. The researcher, with the aid of Statistical Package for Social Sciences (SPSS) and Microsoft excel presented the final data in charts, tables, figures and diagrams. Then descriptive method of analysis which includes both quantitative and qualitative method of analysis was used to analyze data collected via questionnaire and interview. The SPSS was used to obtain frequencies and percentages of close ended responses; and open ended responses were analyzed in a qualitative manner.

\section{Results and Discussion}

\subsection{The current Status of Enterprise}

Capital formation and employment opportunities determine the current status and trends of micro and small scale enterprises (MSEs). The information about the enterprises illustrates that $60 \%$ of enterprises were small scale enterprises followed by micro scale enterprises that accounts $22.5 \%$ and the rest $10 \%$ of enterprises were above micro and small scale enterprises. This suggests that the majority of the enterprises that operate in Worde 14 of Kolfe keranio sub city are small scale enterprises followed micro scale enterprises.

Figure 1: Status of the Enterprises

\section{Proportion of Enterprise Status}



Source: own survey, 2015

The status of the enterprises is changing from time to time as its capital and workers are increasing. For instance in Woreda 14 of Kolfe keranio sub city around $37.5 \%$ of manufacturing sector was graduated and jumped to small scale enterprises due the existence of high experience and partner ownership structure. 
Similarly 23 of construction, 6 of manufacturing and 4 of service enterprise were graduated and jumped to small enterprises at the age of more than five years. However, the graduation of micro and small scale enterprises affected by lack of selling place, lack of infrastructure, lack of experience sharing from other successful (graduated) enterprises, and reluctance of the members to work together in collaboration with their fellow members and in partnership with other MSEs. Correspondingly bureaucratic bottlenecks, poor implementation capacity of workers, weak institutional structures, lack of commitment among the officials and their subordinates, absence of training and poor monitoring and controlling were hindered the graduation time of the enterprises.

Figure 2: Total Percentage of Small Enterprise in the Woreda 14 of Kolfe keranio sub city

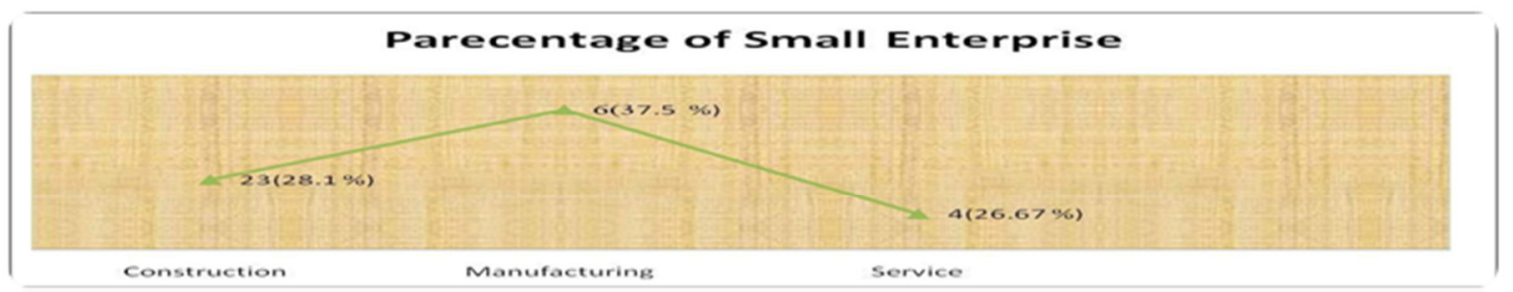

Source: own survey data, 2015

\subsection{Business Formality /Legality}

In developing countries informal business is very common and remains tricky in bringing economic growth and development. Full registration of enterprise reduces the prevalence of informality in to economy as most of them learn paying taxes and discharging all the duties pertaining to them at a very young age.

Table 3: State of Registration of the MSEs in Woreda 14 of Kolfe Keranio sub city

\begin{tabular}{|l|l|l|l|l|l|l|}
\hline \multirow{2}{*}{ Types of Enterprises } & \multicolumn{4}{l}{ Registered /unregistered Enterprises } & \multicolumn{2}{c|}{ Total } \\
\cline { 2 - 7 } & Yes & No & N & $\%$ & N & $\%$ \\
\cline { 2 - 7 } & N & $\%$ & - & - & 29 & 100 \\
\hline Construction & 29 & 100 & - & - & 6 & 100 \\
\hline Manufacturing & 6 & 100 & - & - & 5 & 100 \\
\hline Service & 5 & 100 & - & - & 40 & 100 \\
\hline Total & 40 & 100 & - & & \\
\hline
\end{tabular}

Source: own survey data, 2015

The above table portrays that all construction, manufacturing and service enterprises were registered and become formal via obtaining license from governments. To check the reality, the head of MSEDO of the woreda were asked and answered that all enterprises have obtained legal license of operating the business. This indicates that about 100 percent of the enterprises (i.e. construction, manufacturing and service) have already obtained license to operate their business. Thus, the governments should bring the activities of all enterprises to the formal channel through registration, provision work place, consultancy and financial assistances.

\subsection{Source of Initial Capital of the Enterprises}

People need finance to establish, run and expand their businesses including MSEs. As a result, the respondents were asked to identify the main source of initial capital to start MSEs among personal savings, loans from micro finance institutions, family, and friends and their response is summarized in below table.

Table 4: Source of Initial Capital of the Enterprises

\begin{tabular}{|l|l|l|l|l|l|l|l|l|}
\hline Source of Initial Capital & \multicolumn{9}{l|}{ Name of enterprises } & \multicolumn{1}{l|}{ \% } \\
\cline { 2 - 10 } & $\mathrm{N}$ & $\%$ & $\mathrm{~N}$ & $\%$ & $\mathrm{~N}$ & $\%$ & $\mathrm{~N}$ & $\%$ \\
\hline Personal saving & 5 & 17.0 & - & - & - & & 5 & 12.5 \\
\hline Loans from Micro finance institutions & 7 & 24.0 & 1 & 16.7 & 1 & 20 & 9 & 22.5 \\
\hline Family & 3 & 10.4 & - & - & 1 & 20 & 4 & 10.0 \\
\hline Support from other body & 2 & 7 & - & - & - & & 2 & 5 \\
\hline $1 \& 2$ & 8 & 27.6 & 4 & 66.7 & 3 & 60 & 15 & 37.5 \\
\hline $1 \& 5$ & 4 & 14 & 1 & 16.7 & & & 5 & 12.5 \\
\hline Total & 29 & 100 & 6 & 100 & 5 & 100 & 40 & 100 \\
\hline
\end{tabular}

Source: own survey, 2015

The above table deals with initial capital of enterprises (i.e. construction, manufacturing, and service enterprises). In this regard $27.6 \%$, of construction, $66.7 \%$ of manufacturing and $60 \%$ of service sectors have got their initial capital from personal savings and loan from financial institutions while $24.1 \%$ of construction, $16.7 \%$ of manufacturing, and $20 \%$ of service enterprises have got their initial capital only from micro finance 
institutions. $10.34 \%$ of construction obtained initial capital to from family members to start their business venture. The largest initial capital $(37.5 \%)$ of all enterprises was acquired from personal saving and loan from micro finance institutions whereas the second shares $(22.5 \%$ )of initial capital was only gained from micro finance institutions. The least initial source of capital was support from other body which accounts $5 \%$ in the three sampled sectors. This shows that the largest initial capital is mainly obtained from personal saving and micro finance institutions.

\subsection{The Roles of MSE in Employment Creation and Income Generation.}

Small and Medium Enterprises (SMEs) including Micro enterprises are playing critical roles for socio-economic development of nation especially in employment and job creation throughout the world. The SME sector is contributing immensely to economic growth, more importantly to employment and job creation in developing countries like Ethiopia.

\subsubsection{Employment Creation}

In Ethiopia, the challenge of employment creation is equivalent to achieving the objective of sustained growth and reduction of poverty. In fact, the reduction of unemployment and ensuring sustainable growth is not a simple activity, and it takes long time to achieve goals. Currently both federal and local governments are tasked with the promotion and expansion of MSEs to create employment opportunities for people to curb unemployment problem.

Table 5: Annual Average of Employment Created in MSEs

\begin{tabular}{|l|l|l|l|l|l|l|l|l|}
\hline \multirow{2}{*}{ Annual average of employment } & \multicolumn{2}{|l|}{ Construction } & \multicolumn{2}{l|}{ Manufacturing } & \multicolumn{2}{l|}{ Service } & \multicolumn{2}{l|}{ Total } \\
\cline { 2 - 10 } & $\mathbf{N}$ & $\mathbf{\%}$ & $\mathbf{N}$ & $\mathbf{\%}$ & $\mathbf{N}$ & $\mathbf{\%}$ & $\mathbf{N}$ & $\mathbf{\%}$ \\
\hline $5-7$ & 3 & 10.34 & 2 & 33.33 & 2 & 40 & 7 & 17.5 \\
\hline $8-11$ & 2 & 6.9 & & - & 2 & 40 & 4 & 10 \\
\hline $9-12$ & 5 & 17.3 & - & - & 1 & 20 & 6 & 15 \\
\hline $13-15$ & 9 & 31 & 1 & 16.67 & - & - & - & - \\
\hline $17-23$ & 8 & 27.6 & 3 & 50 & - & - & - & - \\
\hline Not stated & 2 & 6.9 & & & - & - & - & - \\
\hline Total & $\mathbf{2 9}$ & $\mathbf{1 0 0 . 0 0}$ & $\mathbf{6}$ & $\mathbf{1 0 0 . 0 0}$ & $\mathbf{5}$ & $\mathbf{1 0 0 . 0 0}$ & $\mathbf{4 0}$ & $\mathbf{1 0 0 . 0 0}$ \\
\hline
\end{tabular}

The contributions of MSMEs to employment by size (share of workers) are different among the constituents of the MSMEs. The national averages for the contribution of MSMEs are about 37, 34, and 11 percent for Micro sized, small and medium sized enterprises respectively. This means that Micro sized firms (with workers between 1 to5) in Ethiopia are employing about 37 percent of the entire labour force in the country with marked differences across the regions. Construction was the most dominant sector in providing crucial employment to the crowded population.

As shown in the above Table out of sampled enterprise most of manufacturing (50\%) have created annual average of employment which ranges from 17-23. 31\% of construction enterprise annual average of employment created between 13-15 was large number of employment created in the sector within five years. $80 \%$ of service sector had created annual average of employment between first and second range (5-7 and 8-11 per years) which was the least annual average of employment created.

The same analysis indicated that majority of construction $(58.6 \%)$ and manufacturing $(66.67 \%)$ enterprise have registered maximum number of annual average employment ranges between13-23. Therefore, the majority of the firms in construction and manufacturing have shown change in their number of annual average of employment created compared to service sector. This figure still reveals the constrained nature of the growth in service sector and the extent of support they need from stakeholder. The analysis made for all the enterprise reveals that around $17.5 \%$ of the MSEs have not registered sufficient annual average growth in employment between their years of establishment and the current period was only 5-7.

This implies that about 50 percent of employment in Woreda 14 of Kolfe Keranio sub city is offered by construction sector followed by manufacturing sectors. This means construction sector succeeded in registering the maximum number of employment opportunities for the people whereas service enterprise was unsuccessful in creating new jobs, it shows most of created employment is range between5-11 per annual.

\subsubsection{Types of Employment Generated in the Enterprises}

As illustrated in table the majority 36\% type of employment that created by MSMEs were contractual employment followed by permanent employment and hired labor which represents $24 \%$ and $20 \%$ respectively. These employments opportunities are different among or between the sectors. Large numbers $75 \%, 40 \%$ and $31 \%$ of the workers employed in the service, manufacturing and construction sectors is contractual type employment. This shows that contractual type of employment is the dominant employment opportunities in service, construction and manufacturing enterprises shadowed by permanent employment, hired labor and seasonal employment. 
In the same way in construction enterprises family labor was found to be the significant source of labor. $27 \%$ of total workers are either paid or unpaid family labors. The existence of family labor helps small enterprises to minimize their cost of operation, but the firms could not tap the best talents from the labor markets (Tegegne \&Mulat, 2005).

Table 6: Types of Employment Generated in the Enterprises

\begin{tabular}{|c|c|c|c|c|c|c|c|c|c|c|c|c|c|c|}
\hline \multirow{3}{*}{$\begin{array}{l}\text { Type of } \\
\text { Enterprise }\end{array}$} & \multicolumn{14}{|c|}{ Types of Employment } \\
\hline & \multicolumn{2}{|c|}{$\begin{array}{l}\text { Permanent } \\
\text { Employee }\end{array}$} & \multicolumn{2}{|c|}{$\begin{array}{l}\text { Contractual } \\
\text { Employee }\end{array}$} & \multicolumn{2}{|c|}{ Hired labor } & \multicolumn{2}{|c|}{ Family } & \multicolumn{2}{|c|}{$\begin{array}{l}\text { Seasonal } \\
\text { employee }\end{array}$} & \multicolumn{2}{|c|}{ Not-stated } & \multicolumn{2}{|c|}{ Total } \\
\hline & $\mathrm{N}$ & $\%$ & $\mathrm{~N}$ & $\%$ & $\mathrm{~N}$ & $\%$ & $\mathrm{~N}$ & $\%$ & $\mathrm{~N}$ & $\%$ & $\mathrm{~N}$ & $\%$ & $\mathrm{~N}$ & $\%$ \\
\hline Construction & 8 & 15 & 16 & 31 & 14 & 27 & 3 & 6 & 6 & 12 & 5 & 10 & 52 & 100 \\
\hline Manufacturing & 9 & 45 & 8 & 40 & 1 & 5 & - & & - & & 2 & 10 & 20 & 100 \\
\hline Service & 1 & 25 & 3 & 75 & - & & - & & - & & - & & 4 & 100 \\
\hline Total & 18 & 24 & 27 & 36 & 15 & 20 & 3 & 4 & 6 & 8 & 7 & 9 & 76 & 100 \\
\hline
\end{tabular}

Source: own survey, 2015

\subsubsection{Five years Annual Average of Employment Created in MSEs}

MSEs are defined in most countries based on the number of employees. Accordingly, most commonly, micro enterprise is enterprises with ten and less employees, while small enterprise is enterprises with 10 to 50 employees (Farbman and Lessik, 1989). But in Ethiopia an enterprise said to be micro when number of an employee's it consists are less than six and small enterprise establishments employing between 6- 30 persons as indicated in chapter two of this research. Data has been collected on the number jobs annually created in sampled enterprises i.e. manufacturing, construction and services enterprises. Consequently, most (50\%) of manufacturing enterprise have produced annual average of employment for 17-23 persons. $31 \%$ of construction enterprise have produced annual average of employment that ranges between $13-15$ persons whereas the least annual average of employment were generated in service sector.

The same analysis shows that majority of construction and manufacturing enterprises have registered maximum number of annual average employment ranges between13-23 persons. This means the majority of construction and manufacturing have shown great change in increasing employment opportunities as compared to service sector. This figure reveals the constrained nature of the growth and the extent of support that provided by stakeholders and other concerned bodies were hindered service sector in generating maximum employment opportunities for people.

Table7: Annual Average of Employment Created in MSEs

\begin{tabular}{|c|c|c|c|c|c|c|c|c|}
\hline \multirow{3}{*}{$\begin{array}{l}\text { Annual average of } \\
\text { employment } \\
\text { created }\end{array}$} & \multicolumn{8}{|c|}{ Types of Enterprise } \\
\hline & \multicolumn{2}{|c|}{ Construction } & \multicolumn{2}{|c|}{ Manufacturing } & \multicolumn{2}{|c|}{ Service } & \multicolumn{2}{|c|}{$\begin{array}{l}\text { Total sampled } \\
\text { enterprise }\end{array}$} \\
\hline & $\mathrm{N}$ & $\%$ & $\mathrm{~N}$ & $\%$ & $\mathrm{~N}$ & $\%$ & $\mathrm{~N}$ & $\%$ \\
\hline $5-7$ & 3 & 10.34 & 2 & 33.33 & 2 & 40 & 7 & 17.5 \\
\hline $8-11$ & 2 & 6.9 & & - & 2 & 40 & 4 & 10 \\
\hline $9-12$ & 5 & 17.3 & - & - & 1 & 20 & 6 & 15 \\
\hline $13-15$ & 9 & 31 & 1 & 16.67 & - & & 10 & 25 \\
\hline $17-23$ & 8 & 27.6 & 3 & 50 & - & & 11 & 27.5 \\
\hline Not stated & 2 & 6.9 & & & - & & 2 & 5 \\
\hline $\begin{array}{l}\text { Total } \\
\text { sampled } \\
\text { Enterprise }\end{array}$ & 29 & 100.00 & 6 & 100.00 & 5 & 100.00 & 410 & 100.00 \\
\hline
\end{tabular}

Source: own survey data, 2015

In Ethiopia the main purpose of micro and small scale enterprises policy is to generate sustainable employment and income for highly growing labor force. In this regard manufacturing sector succeeded in registering the maximum number of employment opportunities. However, service enterprise was unsuccessful in generating job opportunities.

\subsubsection{Income Generation}

\subsubsection{Initial Capital of the enterprises}

The capital of the enterprises (i.e. initial capital and current capital) determines the amount of income generated by the enterprises. Concerning the initial investment of service sector was found to be low and less than or equal to 5,000 birr. Most of manufacturing and construction sectors initial investment capital was ranged between 10,000-20,000 birr and 80,000 -100,000 birr respectively. This low initial investment highly restricted the group based micro and small scale enterprises in generating income for both the owners and employees of the enterprises. 
Table 8: Initial Capital Level of Enterprise

\begin{tabular}{|c|c|c|c|c|c|c|c|c|}
\hline \multirow[t]{2}{*}{ Range of initial } & \multicolumn{2}{|c|}{ Construction } & \multicolumn{2}{|c|}{ Manufacturing } & \multicolumn{2}{|c|}{ Service } & \multirow{2}{*}{$\frac{\text { Total }}{\mathrm{N}}$} & \multirow[b]{2}{*}{$\%$} \\
\hline & $\mathrm{N}$ & $\%$ & $\mathrm{~N}$ & $\%$ & $\mathrm{~N}$ & $\%$ & & \\
\hline$\geq 5000$ & - & - & 1 & 16.67 & 3 & 75 & 3 & 7.5 \\
\hline $10,000-20,000$ & 4 & 13.8 & 2 & 33.33 & 1 & 20 & 7 & 17.5 \\
\hline & & & & & & & & \\
\hline $20,001-50,000$ & 3 & 10.34 & - & - & 1 & 25 & 5 & 12.5 \\
\hline $50,001-80,000$ & 6 & 20.7 & - & - & - & - & 6 & 15 \\
\hline $80,001-100,000$ & 8 & 27.6 & - & - & - & - & 8 & 20 \\
\hline $100,001-120,000$ & 4 & 13.8 & 1 & 16.67 & - & - & 5 & 12.5 \\
\hline $120,001-150,000$ & 2 & 6.9 & 2 & 33.33 & - & - & 4 & 10 \\
\hline Not stated & 2 & 6.9 & - & - & - & - & 2 & 5 \\
\hline Total & 29 & 100.00 & 6 & 100.00 & 5 & 100. & 40 & 100.00 \\
\hline
\end{tabular}

Source: own survey data, 2015

\subsubsection{Monthly Sales of Enterprise}

Income generated by business enterprises in general and micro and small scale enterprises in particular is hardly estimated due to poor record keeping. The survey results shows that $27.5 \%$ and $17.5 \%$ of monthly sales of micro and small enterprises was between 5,001-10,000 and more than 10,000 birr respectively whereas $15 \%$ and $12.5 \%$ monthly sales of the enterprises was less than 1000 and 10, 01-2000 birr respectively.Correspondingly the study result shows $5 \%$ of micro and small enterprises have monthly sales of less or equal to 500 birr. This monthly sales is differ from sector to sector. $10.34 \%$ of the construction and $40 \%$ of service sector monthly sale were between $1001-2,000$ birr. $50 \%$ of manufacturing sector and $24 \%$ of construction sector monthly sale was more than 10,000 birr. This implies that the monthly sales of micro and small scale enterprises is low and remain challenging in generating adequate income for both owners and employees of the enterprises.

Table 9: Monthly Sales of enterprise

\begin{tabular}{|c|c|c|c|c|c|c|c|c|}
\hline \multirow{2}{*}{$\begin{array}{l}\text { Income of MSEs Owners } \\
\text { per year }\end{array}$} & \multicolumn{2}{|c|}{ Construction } & \multicolumn{2}{|c|}{ Manufacturing } & \multicolumn{2}{|c|}{ Service } & \multicolumn{2}{|l|}{ Total } \\
\hline & $\mathrm{N}$ & $\%$ & $\mathrm{~N}$ & $\%$ & $\mathrm{~N}$ & $\%$ & $\mathrm{~N}$ & $\%$ \\
\hline$<500$ & 2 & 6.9 & - & - & - & - & 2 & 5 \\
\hline $501-1000$ & 4 & 13.8 & - & - & - & - & 4 & 10 \\
\hline $1001-2000$ & 3 & 10.34 & - & - & 2 & 40 & 5 & 12.5 \\
\hline $2001-5000$ & 6 & 20.7 & 1 & 16.67 & 1 & 20 & 8 & 20 \\
\hline $5001-10,000$ & 5 & 17.00 & 1 & 16.67 & 2 & 40 & 11 & 27.5 \\
\hline$>10,000$ & 7 & 24.00 & 3 & 50.00 & - & - & 7 & 17.5 \\
\hline Not stated & 2 & 7.00 & 1 & 16.67 & - & - & 3 & 7.4 \\
\hline Total & 29 & 100.00 & 6 & 100.00 & 5 & 100.00 & 40.00 & 100.00 \\
\hline
\end{tabular}

Source: own survey, 2015

\subsubsection{Current Capital of the Enterprises}

According to the survey result, $22.5 \%$ of micro and small scale enterprises have the current capital of either $120,000-500,000$ birr or 1,000,000 - 1,800,000 birr. Specifically 50\% manufacturing sector had the current capital between 60,000- 120,000 birr.

Table10: Current Capital of the Enterprises

\begin{tabular}{|l|l|l|l|l|l|l|l|l|}
\hline \multirow{2}{*}{$\begin{array}{l}\text { Range of Current } \\
\text { Capital in Birr }\end{array}$} & \multicolumn{2}{l|}{ Construction } & \multicolumn{2}{l|}{ Manufacturing } & \multicolumn{2}{l|}{ Service } & \multicolumn{2}{l|}{ Total } \\
\cline { 2 - 10 } & $\mathrm{N}$ & $\%$ & $\mathrm{~N}$ & $\%$ & $\mathrm{~N}$ & $\%$ & $\mathrm{~N}$ & $\%$ \\
\hline$<60,000$ & - & & - & & 3 & 60 & 3 & 7.50 \\
\hline $60,001-120,000$ & 2 & 7.00 & 1 & 16.70 & - & - & 4 & 10.00 \\
\hline $60,001-120,000$ & - & - & - & - & 2 & 40 & 2 & 5.00 \\
\hline $120,001-500,000$ & 9 & 31.0 & - & - & - & - & 9 & 22.50 \\
\hline $500,001-600,000$ & 2 & 7.00 & - & - & - & - & 2 & 5.00 \\
\hline $600,001-1,000,000$ & 3 & 10.00 & 1 & 16.70 & - & - & 4 & 10.00 \\
\hline $1,000,001-1,800,000$ & 7 & 24.00 & 3 & 50.00 & - & & 9 & 22.50 \\
\hline$>1,800,00$ & 6 & 22.00 & 1 & 16.70 & - & & 7 & 17.50 \\
\hline Total & 29 & 100.00 & 6 & 100.00 & 5 & 100.00 & 40 & 100.00 \\
\hline
\end{tabular}

Source: own survey, 2015

As shown in the above table $31 \%$ construction sector had the current capital between $120,000-500,000$ birr. And $24 \%$ and $22 \%$ of construction enterprise had the capital of 1,000,000 - 1,800,000 birr and more than $1,800,000$ birr respectively. Similarly $60 \%$ of service sector had the current capital of less than 60,000 birr 
whereas as the rest $40 \%$ of them had the capital of $60,000-120,000$ birr. This implies that the capital of micro and small scale enterprises is increasing and have reached more than half million birr peer year.

The current capital of construction and manufacturing enterprises are relatively increasing and have still significant role in developing and running new business ventures to produce more job opportunities and income for the people. However, lack of fund to start business, ideas or information about the business, product market, high prices and high rent of building, market imperfection and high tax rates were restricted micro and small scale enterprises in generating more jobs and income in woreda 14 of Kolfe Keranio sub city.

\section{Conclusion and Recommendations \\ 5.1 Conclusion}

Micro and Small Enterprises has won recognitions in the economy of developed and developing countries. Particularly it plays a vital role in employment creation and income generation for the large sections of unskilled and semi-skilled labor force in developing countries which has stimulated significant interest among policy makers and practitioners alike. The main focus of study is to assess the contribution of group-based MSEs in employment creation and income generation in Woreda 14 of Kolfe keranio by analyzing the performance of construction, manufacturing and service sectors. These different sectors were taken in order to see the contribution they had to employment creation and income generation.

The survey shows that the current status of all enterprises that established and operated in woreda 14 of Kolfe keranio sub city were not similar. The majority $62.5 \%$ of the enterprises were operated under small scale enterprises whereas $20 \%$ of the enterprises were operated under micro enterprises. The starting up capital of the enterprises was mainly acquired from personal saving and loan from financial institutions. The size of initial capital of the three MSEs for starting their activities ranges between 5000 birr and 150,000 birr. The majority of service enterprise (60\%) has less than or equal to 60,000birr current capital. Whereas, around $79.34 \%$ and $50 \%$ of construction and manufacturing sectors have more than 120,000 birr and 1 million birr current capital respectively.

In producing job opportunities and income for the people MSEs plays significant role. For instance manufacturing and construction enterprise were ranked first and second in creating job opportunities for job seekers. In this context, most manufacturing enterprises were created permanent employment opportunities whereas most of service and construction sectors were created contractual employment opportunities for job seekers. Moreover, MSEs has played substantial role in income generation for the people and their contribution depends on the monthly sales of the enterprises. Thus, monthly sale of construction and service sectors were less than that of manufacturing sector. The least monthly sale of manufacturing sector is more than 2000 birr and their maximum monthly sale is 10,000 birr and above. Inversely, service sector was found to be the least interims of its monthly sale.

Likewise annual income of the sampled enterprises was not the same or equal. More productive enterprise like manufacturing enterprise has registered high annual average income that ranges between 100,000-200,000 birr whereas the lowest annual average income has registered in service sector. Furthermore, lack of premise, market, and shortage of finance, bankruptcy, disagreement between members and complex government rules and regulation were constrained the growth and success of the enterprises in generating income and job opportunities in Woreda 14 of Kolfe Keranio sub city.

\subsection{Recommendations}

Based on the major findings of the study the following recommendations were forwarded to improve the contribution of group- based micro and small enterprises in employment and income generation.

The role of MSEs in boosting employment opportunities and income generation has been undeniable. However, government body including the governor of Woreda 14 of Kolfe Keranio sub city should pick the sectors that employ more people and channel the resources and assistance to the enterprises.

Since there information gap on the status of the enterprises, local governments and other concerned bodies needs to conduct researches that successfully reduce the information gap and identifies status of the enterprises.

Service enterprises are the least performer in creating job opportunities and income generation compared to the other two enterprises. Therefore the governments should encourage owners and managers of enterprises via training and assistance services in order to increase their contribution in employment creation and income oeneration.

The governments should encourage the culture of saving and innovative capacity of the enterprises via designing and providing different training programs.

The governments should identify the needs and interests of the enterprise and provide them all necessary supports like market, finance, work place, credit facility and infrastructure that makes them self-independent.

The problems like bureaucratic working procedures and governance should be eliminated and working 
procedure should be modernized through implementation of various reform programs.

\section{References}

- Aklilu, W. (2010). Analysis of Marketing Practices in Micro and Small Enterprises (MSEs) The Case of Metal and Wood work MSEs in Mekelle City, Tigray, Ethiopia; MA Research Thesis Mekelle University.

- Agyapong, D.2010. Micro, Small and Medium Enterprises' Activities, Income Level and Poverty Reduction in Ghana - A Synthesis of Related Literature .International Journal of Business and Management 5, 196-205.

- Ayyagari, Meghana, Asli Demirguc-Kunt and Vojislav Maksimovic, 2011a. Firm Innovation in Emerging Markets: The Role of Finance, Governance, and Competition. Journal of Financial and Quantitative Analysis 46, 1545-80.

- Beck, T, Demirguc-Kunt, A., \& Levine, R. (2004). Finance, Inequality, and Poverty: Cross-Country Evidence. Working Paper No. 10979: National Bureau of Economic Research.

- Belay kinati Debelo , AsmeraTeshome, Tekalign Minalu (2015), Factors Affecting Development of MSEs. International Journal of Scientific and Research Publications, Volume 5, Issue 1, January 20151 ISSN 2250-3153.

- Bereket Tadesse, (2010). The Role of Micro and Small Enterprises in Employment Creation and Income Generation a Survey Study of Mekelle City, Tigray Region, Ethiopia

- Berihu Assefa, Abebaw Zerfu, and Biruk Tekle,(2014), Identifying Key Success Factors And Constraints In Ethiopia's MSE Development: Research Report 18, Addis Ababa

- C.R.Kothari,1990, Research Methodology, $2^{\text {nd }}$, New Age International (P) Ltd., Publishers, Jaipur (India)

- Central Statistical Authority (2010), Analyzed Report on meaning and status of MSEs

- Daniels, L. \& Mead, D. C. 1998. The Contribution of Small Enterprises to Household and National Income in Kenya, Economic Development and Cultural Change 47, 45

- Dawson, J. (1997). Beyond credit - the emergence of high-impact,cost-effective business development services. Small Enterprise Development, 8(3), 15-26.

- Dr Catherine Dawson, 2002, Practical Research Methods A User-Friendly Guide to Mastering Research Techniques and Projects, How To Books Ltd, 3 Newtec Place, United Kingdom

- Endalkachew Mulugeta (2008). Underlying causes of micro and small business enterprises failure in Addis ketema sub city. A thesis submitted to the department of Regional and local Development studies, Addis Ababa University, pp100-106.

- Endalsasa Belay (2012). The Contribution of Group-Based Micro and Small Enterprises to the Local Economy and Social Development in the Arada Sub City: A Case Study on Metal and Wood Work Enterprises, Addis Ababa University

- Eversole, R. (2003). My Business Pays Me: Labourers and Entrepreneurs Among the Self Employed Poor in Latin America. Bulletin of Latin American Research, 22(1), 102-116.

- Farbman M. and Lessik A., (1989) The Impact of Classification on Policy‘, in A. Gosses et al. (eds), Small Enterprises, New Approaches. The Hague: Ministry of Foreign Affairs, Directorate of International Cooperation.

- Federal Democratic Republic of Ethiopia (FDRE), Population Census Commission, Central Statistical Agency (CSA).2010.The 2007 Population and Housing Census of Ethiopia, Results for Addis Ababa City Administration. Statistical Report. Addis Ababa, Ethiopia.

- Gebrehiwot A. \& Wolday A., (2005), Policy Impact and Regulatory Challenges of Micro and Small Enterprises in Ethiopia. Presented at the Second International Conference on the Ethiopian Economy of the Ethiopian Economic Association, Addis Ababa.

- Giddens, Anthony, (1989) Sociology and McNeill, P. Research Methods, London, Routledge. Gomez, G.M.2008.Do Microenterprises Promote Equity or Growth? Evaluation Report Woorden Daad. Gorinchem, The Netherlands.

- Hewaliyang Rekha (2002), Definition of micro and small enterprises in some Asian countries (Article.)

- International Labor Organization, (2002), Women and men in the informal economy: a statistical picture. International Labor Office, ILO Geneva.

- Kolfe Keranio, 2006/20014.The Atlas of Kolfe keraniyo, Addis Ababa City Administration Integrated Land information.

- Kolfe keranio sub-city woreda 14, 2015, Micro and Small Enterprise Report. Addis Ababa Liedholm, Carl, and Mead, C. Donald (1999). Small Enterprises and Economic Development: The Dynamics of micro and small enterprises, Rutledge Studies in Development Economics, New York.

- Liedholm, Carl. 2002. - Small Firm Dynamics: Evidence from African and Latin America. Small Business Economics, 18, 1-3: 227-242.

- Ministry of Finance and Economic Development (MoFED),(2010), Growth and Transformation Plan (GTP) 
2010/11-2014/15 Draft, Addis Ababa

- Ministry of Trade and Industry, (1997), Micro and Small Enterprise Development Strategy; Federal Democratic Republic of Ethiopia, Addis Ababa.

- Mead, D.C., \& Liedholm, C. (1998). The Dynamics of Micro and Small Enterprises in Developing Countries. World Development, 26(1), 61-74.

- Ministry of Urban Development and Construction,(2013), Survey on Micro and Small Enterprises (MSEs) in Selected Major Cities of Ethiopia, Addis Ababa

- Mkandawire T., (1999), Developmental States and Small enterprises in Africa between Poverty and Growth e.d by Kenneth King \& Simon Mc Grath Intermediate Technology.

- Moyi, E. and Njiraini, P. (2005), Towards Technology Models for Micro and Small Enterprises in Kenya: Common Principles and Best Practices. Discussion Paper No 51, Productive Sector Division, Kenya Institute for Public Policy Research and Analysis, Nairobi, Kenya.

- Mukras, M.S.2003. Poverty Reduction through Strengthening Small and Medium Enterprises. Botswana Journal of African Studies17, 58-69.

- Mulugete Yohanis, 2011. The Livelihoods Reality of Micro And Small Enterprise Operators: Evidences From Woreda One Of Lideta Sub-City, Addis Ababa, Ethiopia.

- Orlando, María Beatriz, and Molly Pollack. February 2000. Microenterprises and Poverty Evidence from Latin America. Washington, DC: Inter-American Development Bank, Sustainable Development Department, Microenterprise Unit.

- Robu M., 2013: The dynamic and importance of SMEs in economy

- Serneels P (2004), The Nature of Unemployment in Urban Ethiopia. Centre for the Study in African Economics Working Paper Working Series. CSAE: Berkely Electronioc Press.

- Rossman, Gretchen B. and Rallis, Sharon F., (1998) Learning in the Field: An Introduction to Qualitative Research, London, Sage Publications, Inc.

- Tegegne G. and Mehret A., (2010), Micro and Small Enterprises as Vehicles for Poverty Reduction, Employment Creation, and Business Development: The Ethiopian Experience. FSS research Report No.6. Addis Ababa: Forum for Social studies.

- Tegegne G. E. and Mulat D... (2005). Small Business in Small Towns of Eastern Amhara Region: Nature and Economic Performance. Journal of Economics, 14(1).

- Thobeche, E. (2000), The Evolution of Development Doctrine: 1950 - 2005

- Wolday A.(2002), The role of finance and business development services in MSEs Development in Ethiopia. Occasional paper no.5 Addis Ababa.

- World Bank. 2001. World Development Indicators.

- Yin,R.(1994). Case study research: Design and methods (2 ${ }^{\text {nd }}$ ed). Beverly Hills, CA: sage Publishing New York. 